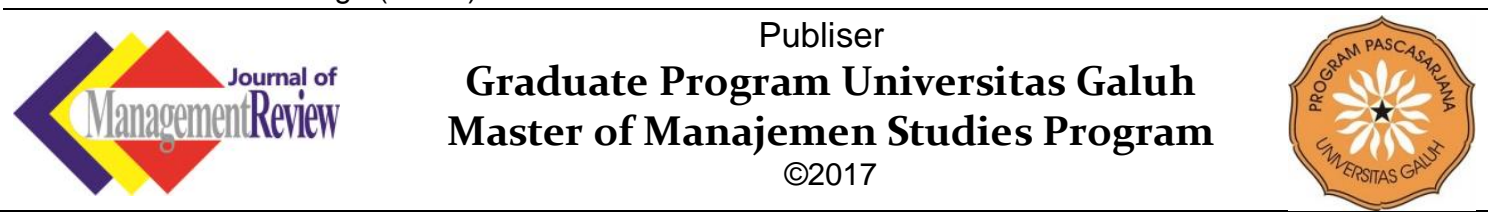

\title{
STRATEGY OF DEVELOPMENT POTENTIAL LAND TO INCREASING INVESTMENT IN CIAMIS REGENCY: STUDY AT REGENCY STRATEGIC AREA (KSK) CORRIDOR OF CIHAURBEUTI-CISAGA
}

\author{
Apri Budianto ${ }^{1}$, Dani Usmar ${ }^{2}$ \\ ${ }^{1}$ Management Studies Program, Faculty of Economics, Universitas Galuh, Jl. R.E. Martadinata \\ No.150 Ciamis.e-mail: apribudianto77@unigal.co.id \\ ${ }^{2}$ Accounting Study Program, Faculty of Economics, Universitas Galuh, Jl. R.E. Martadinata No. \\ 150 Ciamis.e-mail: nieus08@gmail.com
}

\author{
Article History : \\ Recieved 17 April 2017 \\ Recieved in revished form \\ 26 April 2017 \\ Acepted 5 May 2017 \\ Available offline 10 May 2017 \\ Available online 10 May 2017
}

Language Transcript : English

Key Words :

Strategy

Potential Land Development

Regency Strategic Area (KSK)

\begin{abstract}
This article aims to examine potential land potential development strategies in increasing the investment in Kabupaten Ciamis, in the Strategic Areas of the Cihaurbeuti-Cisaga Primary Road Corridor (KSK) Corridor. Prepare data and information potential development potential of potential land (asset area) in increasing the investment in Ciamis Regency, in District Strategic Areas (KSK) Cihaurbeuti-Cisaga Primary Artery Road Corridor which then made the master document of potential data center economic object. The Research Method used is the Analytical Hierarchy Process (AHP) is a functional hierarchy with the main input is human perception. With the hierarchy, a complex and unstructured problem is solved into its group, which is then organized into a hierarchical form. The result of this research is 4 (four) potential of potential land area located in District Strategic Area (KSK) of Cihaurbeuti-Cisaga Primary Artery Road Corridor. There are 3 (three) potential land (potential assets) that occupy position 3 (three ) Which has high potential to be developed, each of which is the Self-Supported Area in Ciamis urban village, Karangmulyan Cultural Heritage Area, Maleber Terminal Export Area. Potential development of potential land (asset area) located in the District Strategic Areas (KSK) of Cihaurbeuti-Cisaga Primary Artery Road Corridor can be implemented through offensive strategy, it is based on the SWOT analysis results Potential potential land (potential assets) The District Strategic Area (KSK) of the Cihaurbeuti-Cisaga Primary Artery Road Corridor is currently at a strong intenal and external factor position. Object conditions have the opportunity to be developed into a tourist area (city tour) and environmentally sustainable superior cultural attractions supported by various elements of strength and opportunity, and minimize weaknesses and threats.
\end{abstract}

\section{INTRODUCTION}

At a time of intense global competition, as well as the declining funding from the central to the regions, local governments must strive to increase Regional Revenues (PAD) to finance regional development and regional expenditure. One source of funds that can be explored in the region is how local governments optimize the potential land owned by local governments and seeks to increase investment both domestically and abroad. With the increasing and effective and efficient use of land owned by the region is expected to attract investors to invest their capital in the area owned area. Thus the local government should always strive to develop the potential possessed by the region so that in the end will increase regional pempatan. Development as a change in the person enabling the concerned to work effectively, According to Hafsah (2000) development is an effort made by the government, business, and community through the provision of guidance and strengthening assistance to grow and improve the ability of small business to be a business Tough and 
independent. While according to Mangkuprawira (2004: 135) states that development is an effort to increase knowledge that may be used immediately or often for the interests of the future. On the other hand development is requiring and involves some sort of direction, arrangement, and guidance in order to create forces for the extension of maintenance. While in a large dictionary of Indonesian language states that development is the way or the work of developing something (work, effort, personality and so forth). From some of the above understanding can be concluded that the development is everything that is done to improve the implementation of current and future jobs provide information, direction, arrangements, and guidelines in business development.

This article aims to design potential land potential development strategies to increase investment in Kabupaten Ciamis, in the Strategic Area of the Cihaurbeuti-Cisaga Primary Road Corridor (KSK) by optimizing the strengths, eliminating the weaknesses, taking advantage of opportunities and avoiding threats encountered.

The objectives of this artkel are 1) Establishment of potential potency (potential asset) area development strategy to increase investment in Ciamis Regency, District Strategic Area (KSK) of Cihaurbeuti-Cisaga Primary Artery Road Corridor, 2) Establishment of recommendation for Local Government of Ciamis Regency about strategy Development of potential land (potential assets) in increasing investment in Kabupaten Ciamis, in the District Strategic Areas (KSK) of Cihaurbeuti-Cisaga Primary Artery Road Corridor.

In order to implement the objectives and suggestions the researcher takes the title or the research tapik is to compile the data and information of potential potency of potential land (potential asset) in increasing the investment in Ciamis Regency, in the Strategic Area of the Cihaurbeuti-Cisaga Primary Road Corridor Then made a master document of potential data center economic objects.

\section{THE METHOD}

The research method that gulier in data yielding is explanatory survey method, that is by data collecting technique which researcher use is observation, documentation, and interview with inporman which is considered to understand the problem in the title of this article, the type of data that researcher is primary data and data secondary. Adpute data processing techniques that penuli use is Analytical Hierarchy Process (AHP) is a functional hierarchy with the main input is the human perception. With a hierarchy, a complex and unstructured problem is solved into its group, which is then organized into a hierarchical form. The working principle of AHP is to simplify a complex, unstructured, strategic and dynamic matter into a part arranged in a hierarchy. By creating a systematic decision structure and a series of calculation procedures, it can generate priority recommendations or the decision weight of each proposed alternative. From a variety of considerations then performed synthesis to determine the variables that have high priority and play a role in influencing the results on the system (Mulyono, 319, 2004). In the preparation of this scale of importance, the benchmark is used as in Table 1.

\section{RESUL AND DISCUSSION}

Based on the overall evaluation of the factors that determine potential land potential (potential assets) in increasing the investment in Kabupaten Ciamis, potential potential land areas (potential assets) in the District Strategic Areas (KSK) of Cihaurbeuti-Cisaga Primary Artery Road Corridor are: Area ex Swadaya with evaluation value 0.380 (1st order); Karangkamulyan Cultural Heritage area with a value of 0.271 ( $2 \mathrm{nd}$ order); Area ex Maleber Terminal with value 0.194 (3rd order); And Kawasan Eks Kelanto Gwan Hien coconut oil with evaluation value of 0.156 (4th order).

To know potential and potential development opportunity of potential area (asset area) to increase investment in Kabupaten Ciamis, in Strategic Area of 
Regency (KSK) Cihaurbeuti-Cisaga Ciamis Primary Road Corridor Ciamis Regency in the future used SWOT analysis (Strenghts, Weakness, Oppertunities And Treats). It is intended to know the factors inhibiting and supporting the development of tourism sector.

Internal factors in this analysis consists of the strength that includes external factors in the form of opportunities and threats. The opportunity for tourism development is to have sufficient land, have sufficient manpower, have the existence of adequate facilities, have tourism kekhas, adequate capacity of Government, while the weakness is the High Production Cost, and inconsistency of profit production. External factors are opportunities and threats. Potential development potential of the land (local assets) is a significant increase in traffic, potential to be a commodity needs investment increase, location in a strategic position, the intensification of vehicle management, the support of government in the field of technology and marketing is adequate, derivative factors are still wide open as well as land area extension, while the threat of development is the area is not competitive, investment cost is expensive and there are many land conversion. More details of SWOT analysis calculations for the management and development of land potential (regional assets) are presented in the Figure 1.

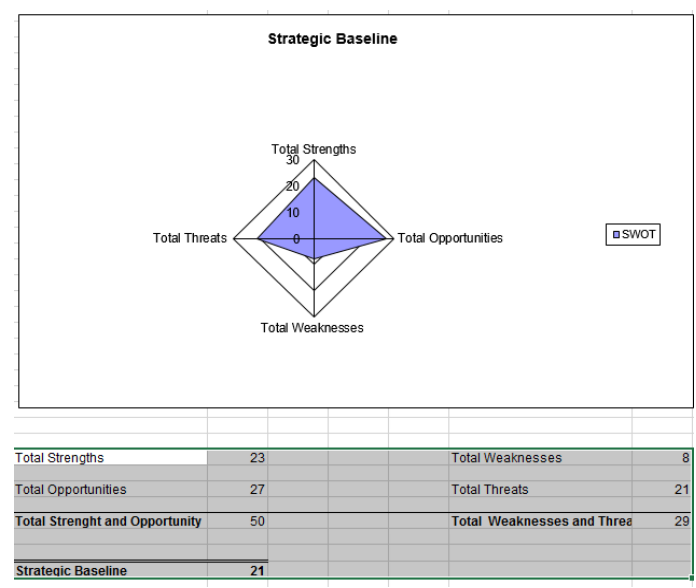

Figure 1. The Strategic Baseline of SWOT Model

Based on the above table can be mapped strengths listed in 4 quadrants, ie quadrant 1 area of aggressive strategy, quadrant 2 minimum area strategy, quadrant 3 areas of defensive strategy, and quadrant 4 areas of diversification strategy. From 3 factors on internal and external indicators, there are 2 main factors that are key to the successful development and potential utilization of potential land (assets) in the District Strategic Areas (KSK) of CihaurbeutiCisaga Primary Artery Road Corridor as presented in the following Table 1 and Tabel 2. The formulation of the strategy can be implemented forestry sector development strategy reffer to the Tabel 3 .

From the result of SWOT matrix analysis and hierarchy analysis that has been done, obtained the sequence of potential object/potential land (asset area) in increasing the investment in Ciamis Regency, in the Strategic Areas of the Cihaurbeuti-Cisaga Primary Road Corridor (KSK) Become a leading tourist attraction. From 4 (four) land (local assets) in this study there are 3 (three) objects that occupy the position of 3 (three) major are as follows: 1) Area ex Swadaya; 2) Karangkamulyan Cultural Heritage Area; 3 ) Area of Terminal Ciamis.

Potential land development (potential assets) in increasing investment in Kabupaten Ciamis, in the District Strategic Areas (KSK) of Cihaurbeuti-Cisaga Primary Artery Road Corridor can not be separated from the right policy and the selection of appropriate strategies. From the results of the study can be formulated various strategies in the development and management of potential land (asset area) in increasing investment in Kabupaten Ciamis, the District Strategic Areas (KSK) Cihaurbeuti-Cisaga Primary Artery Road Corridor is as follows:

1. Referring to the needs of Ciamis community related to entertainment, tourism.

2. Formulate the arrangement and utilization of land (potential assets).

3. Supporting Regional Investment Development especially entertainment and tourism

4. Increase promotion in the search for market opportunities Regional Investment, especially entertainment and tourism

5. As well as improving the quality of objects / land owned by the government 
for increasing PAD by keeping paying attention to local kearipan

6. Mapping the area of potential Investment Area especially tourism potential.

7. The development and improvement of a plenary infrastructure.

The following is a crucial urgent program in the handling of the increase of the Original Regional Revenue agreed in the Focus Group Discussion together with the bureaucracy and stakeholders in improving the investment climate:

1. The development Area (block) of the Ex-Swadaya has the potential as a Town Entertainment center, whose development should be based on sustainable development that is oriented to the principles of:

- The first principle is the development of city tourism should be built by involving local communities

- The second principle is the development of city tourism should create a balance between the needs of tourists and the public. The interest of community economic empowerment is a goal based on the willingness to shape the quality of tourism destinations expected by tourists. The balance will be realized if all parties can work together in one goal as a solid community. The community in question is the local community

- The third principle is that urban tourism development should involve stakeholders, and involving more parties will get better input. Stakeholder engagement should be able to accommodate the opinions of local CSOs, involving marginal or poor communities, involving women, involving tourism associations, and other groups in communities that have the potential to influence the course of development in a harmony

- The fourth principle is, the development of city tourism should provide convenience to local entrepreneurs in small and medium scale.
- The fifth principle is that urban tourism development should be conditioned for the purpose of generating other business "multiflier effects" either directly or indirectly in the community means that tourism should have multiplier effects on other sectors, both new businesses and businesses that have grown today.

- The sixth principle is the development of urban tourism should the existence of cooperation between local communities as a creator of tourist attractions with the operators selling tour packages, so need to build mutually beneficial cooperation relationship.

- The seventh principle is, the development of city tourism should be able to guarantee sustainability, provide benefits for the society today and not harming the next generation

- The eighth principle is that urban tourism development should grow in the principle of optimization rather than exploitation

- The ninth principle is that the development of city tourism should be periodically monitored and evaluated to ensure that tourism development continues in the concept of sustainable development. Tourism development should be placed on the principle of management with capacity management, both regional capacity, the capacity of certain attractions, economic capacity, social capacity, and other resource capacities

- The tenth principle is that urban tourism development should be open to the use of resources such as underground water use, land use, and other resource use should be ascertained properly.

- The eleventh principle is that urban tourism development should undertake human resources improvement program in the form of education, training and certification for tourism expertise so that it can be assured that the workers are ready to 
work in accordance with the task description that has been set in accordance with their respective fields

- The twelfth principle is the development of city tourism should be the realization of the three qualities of tourism should be able to realize the quality of life "quality of life" of local communities, on the other side of tourism should be able to provide quality "quality of opportunity" to service providers in the tourism industry and next and to be the most important is the creation of quality experience of tourists "quality of experience".

2. Considering the strategic location in the center of the city, the development of the Self-developed Area will be more productive if the development is the development of the block / region so that the local government must have political will to convert the block's function which in the existing consis- tance there are 28 units of ruko building into entertainment areas (city tour) integrated with hawker center (culinary).

3. Development should pay attention to the analysis of community needs of Ciamis who yearn for entertainment facilities / places integrated with other supporting facilities. The location of ex-selfsupporting areas is very strategic if developed into a means of hanging out (City Tour) in Ciamis, considering the very strategic location in the city center. Of course this needs to be supplemented by further technical follow-up.

4. Maleber Terminal Area, considered as follows:

- To develop kasawan eks terminal maleber must pay attention to the existing condition of the land as land (asset) of Maleber urban village which must be settled immediately.

- Must pay attention to the market and marketing aspects.

- This area is potential to be developed with due regard to the current location, besides of course must pay attention to the geographical location of the area, which requires adequate supporting facilities planning and requires a comprehensive study if it will be developed into an electronic goods sales center integrated with other shopping centers.

- Taking into account the needs of supporting facilities such as parking lots and so on.

5. Kangkaan cultural preserve Karangkamulyan, considered as follows:

- For the development of Karangkamulyan Cultural Heritage must be oriented to the development and development of sustainable tourism.

- Increase the perception and appreciation of tourists to increase tourist visits with the development of tourism potential that is fully supported by the government, with the active participation of private parties and communities

- To strengthen the institutions (capacity building) by conducting various trainings and other capacity building to the community and the government for the management of the tourist area to a better direction;

- Efforts to preserve the environment by repairing damage to various ecosystems;

- Increasing public and tourist awareness of the cleanliness of the environment around the object of tourism, Improving the quality and quantity of facilities supporting facilities on every potential tourism object;

- Making programs and events by developing various cultural potentials around;

- Increase public awareness about culture and customs with the community itself which is original and has economic value; - Improved bureaucratic reform effort; The addition of supporting facilities and infrastructure of tourism object; Integrate any potential tourism object with other nearby tourism objects or with other tourism economic potentials; Enhance public education 
and tourism management to socialize government regulations and improve security and tourism awareness.

In the development of potential potential land (asset area) located in the District Strategic Area (KSK) of CihaurbeutiCisaga Primary Artery Road Corridor into tourist sites (city tour and cultural heritage tourism), planning, market and marketing (promotion) is the most potential effort do. To be able to implement these recommendations, the main program to watch out for:

- Existing and sustainable integrated and integrated planning;

- Infrastructure development program on spot and out spot;

- Resource development programs;

- Tourism technology development program;

- Institutional development programs;

- Tourism development and promotion program;

Exploration The development of potential potential land (asset area) objects located in the District Strategic Areas (KSK) of the Cihaurbeuti-Cisaga Primary Road Corridor and other corridors requires a clear and implementative development model and milestone model supported by the government, with participation active from private parties and the public.

\section{CONCLUSION}

Whereas from 4 (four) potential land (potential assets) located in the District Strategic Areas (KSK) of CihaurbeutiCisaga Primary Artery Road Corridor there are 3 (three) potential land (potential assets) that occupy the position of 3 (three) High potential to be developed each of which is the Self-Help Area in the village of Ciamis, Karangmulyan Cultural Heritage Area, Maleber Terminal Ex-Terminal Area. Potential development of potential land (asset area) located in the District Strategic Areas (KSK) of Cihaurbeuti-Cisaga Primary Artery Road Corridor can be implemented through offensive strategy, it is based on the SWOT analysis results Potential potential land (potential assets) The District Strategic Area (KSK) of the Cihaurbeuti-Cisaga Primary Artery Road
Corridor is currently at a strong intenal and external factor position. Object conditions have the opportunity to be developed into a tourist area (city tour) and environmentally sustainable superior cultural attractions supported by various elements of strength and opportunity, and minimize weaknesses and threats. The development and management of potential objects and potential of potential located in the District Strategic Areas (KSK) of the CihaurbeutiCisaga Primary Artery Road Corridor can be done with due regard to the existing condition, sustainability and sustainability of nature and culture.

\section{ACKNOWLEGDEMENT}

This article is supported by Dinas Penanaman Modal dan Pelayanan Terpadu Satu Pintu (DPMPTSP) of Ciamis Regency. At this opportunity, the researchers would like to thank Kepala Dinas DPMPTSP of Ciamis Regency, Galuh Education Foundation, Galuh University Rector and its Staff, Dean of Faculty of Economics and its staff, and Graduate Director of Galuh Ciamis University and all staff of Journal of Management Review.

\section{REFERENCE}

Damanik J. \& Weber, H, 2006, Perencanaan Ekowisata dari Teori ke Aplikai, Yogyakarta : PUSPAR UGM \& Andi

Hafsah, JM., 2000, Kemitraan Uaha Konsepsi dan Strategi, Jakarta, Puat Sinar Harapan

Mangkuprawira, S., 2004, Manajemen Sumber Daya Manuia Strategik, Jakarta, Ghalia Indonesia

Meyer, K. 2009, Pnaduan Pelaksanaan Ekowisata, Jakarta, Uneco Office.

Suswantoro, G., 2007, Dasar-Dasar Pariwisata, Yogyakarta, Andi Offset

Undang-Undang Republik Indonesia Nomor 10 Tahun 2009 tentang Kepariwisataan 


\section{Appendix}

Tabel 1. Factors of Successful Development and Utilization of Potential Land (Potential) Potential in Regency Strategic Areas (Ksk) Corridor of Cihaurbeuti-Cisaga Primary Artery Road

\begin{tabular}{|c|c|}
\hline \multicolumn{2}{|c|}{ Internal Factor } \\
\hline Strength (S) & Weakness (W) \\
\hline $\begin{array}{ll}\text { - } & \text { Input } \\
\text { - } & \text { Labor } \\
\text { - } & \text { External Support Capacity } \\
\text { - } & \text { Internal Support Capacity } \\
\text { - } & \text { Land Available Wide enough } \\
\text { - } & \text { Have Land Sufficiency } \\
\text { - } & \text { Have Sufficient Manpower And Experts } \\
\text { - } & \text { Has The Existence Of Adequate Facilities } \\
\text { - } & \text { Has Unification } \\
\text { - } & \text { Adequate Government Support Capacity } \\
\text { - } & \text { The Existence Of Adequate Partners } \\
\text { - } & \text { Has Adequate Technology } \\
\text { - } & \text { Support to Quality Management Improvement }\end{array}$ & $\begin{array}{ll}\text { - } & \text { High Production Cost } \\
\text { - } & \text { Inconsistent / overlapping rules } \\
\text { - } & \text { Less Have the Supporting Capacity of Land } \\
& \text { Management } \\
\text { - } & \text { Land status msh leased to Individual }\end{array}$ \\
\hline Opportunity (O) & Threat (T) \\
\hline $\begin{array}{ll}\text { - } & \text { Higher Visit Increase } \\
\text { - } & \text { Potential of Tour and Travel Needs } \\
\text { - } & \text { Strategic location } \\
\text { - } & \text { Intensification in Easy Management } \\
\text { - } & \text { Supporting Capacity of Government in the field of } \\
& \text { Technology and Investment Sufficient/Power of } \\
& \text { Government Support Regulation in Spatial Planning } \\
\text { - } & \text { Power of Government Support in Regional } \\
\text { - } & \text { Exarketing } \\
\text { - } & \text { Derivative Factors Still Open } \\
\text { - } & \text { - Potential to be an Entertainment Area }\end{array}$ & $\begin{array}{ll}\text { - } & \text { Land clearing } \\
\text { - } & \text { Entrance culture from outside } \\
\text { - } & \text { Competition object Entertainment and tourism in } \\
& \text { Ciamis District } \\
\text { - } & \text { Increase in garbage volume } \\
\text { - } & \text { Increased volume of vehicles and traffic } \\
\text { - } & \text { Increased public disease }\end{array}$ \\
\hline
\end{tabular}


Tabel 2. Formulation of Tourism Sector Development Strategy In Banjarsari District, Ciamis Regency

\begin{tabular}{|c|c|c|}
\hline Internal Factor & Strength $(\mathrm{S})$ & Weakness (W) \\
\hline & $\begin{array}{l}\text { - Input } \\
\text { - Labor } \\
\text { - External Support Capacity } \\
\text { - Internal Support Capacity } \\
\text { - Land Available Wide enough } \\
\text { - Have Land Sufficiency } \\
\text { - Have Sufficient Manpower And } \\
\text { Experts } \\
\text { - Has The Existence Of Adequate } \\
\text { Facilities } \\
\text { - Has Unification } \\
\text { - Adequate Government Support } \\
\text { Capacity } \\
\text { - The Existence Of Adequate } \\
\text { Partners } \\
\text { - Has Adequate Technology } \\
\text { - Support to Quality Management } \\
\text { Improvement }\end{array}$ & $\begin{array}{l}\text { - } \text { High Production Cost } \\
\text { - } \text { Inconsistent / overlapping rules } \\
\text { - } \text { Less Have the Supporting } \\
\text { Capacity of Land Management } \\
\text { - Land status msh leased to } \\
\text { Individual }\end{array}$ \\
\hline \multicolumn{3}{|l|}{ External Factor } \\
\hline Opportunity $(\mathrm{O})$ & Strategy (S-O) & Strategy $(\mathrm{W}-\mathrm{O})$ \\
\hline $\begin{array}{l}\text { - Higher Visit Increase } \\
\text { - Potential of Tour and Travel Needs } \\
\text { - Strategic location } \\
\text { - Intensification in Easy Management } \\
\text { - Supporting Capacity of Government in } \\
\text { the field of Technology and Investment } \\
\text { Sufficient/Power of Government } \\
\text { Support Regulation in Spatial Planning } \\
\text { - Power of Government Support in } \\
\text { Regional Marketing } \\
\text { - Extensification of Tourism and } \\
\text { Entertainment Land } \\
\text { - Derivative Factors Still Open } \\
\text { - Potential to be an Entertainment Area } \\
\end{array}$ & $\begin{array}{l}\text { Develop tourism commodities } \\
\text { especially those with high traffic } \\
\text { numbers both in local and foreign } \\
\text { tourists }\end{array}$ & $\begin{array}{l}\text { - Increasing tourism promotion } \\
\text { - Improve existing tourist rides }\end{array}$ \\
\hline Threat $(\mathrm{T})$ & Strategy $(\mathrm{O}-\mathrm{T})$ & Strategy $(\mathrm{W}-\mathrm{T})$ \\
\hline $\begin{array}{l}\text { - Land clearing } \\
\text { - Entrance culture from outside } \\
\text { - Competition object Entertainment and } \\
\text { tourism in Ciamis District } \\
\text { - Increase in garbage volume } \\
\text { - Increased volume of vehicles and traffic } \\
\text { - Increased public disease }\end{array}$ & Improve the quality of facilities & $\begin{array}{l}\text { Always pay attention to the quality } \\
\text { of facilities and infrastructure and } \\
\text { improve the service With due regard } \\
\text { to local cultural wisdom }\end{array}$ \\
\hline
\end{tabular}

Tabel 3. Implementation of Tourism Sector Development Strategy in Banjarsari District Ciamis Regency

\begin{tabular}{|c|c|c|c|}
\hline Strategy & Policy & Programs & Action \\
\hline $\begin{array}{l}\text { Land development (local } \\
\text { assets) Potential due to } \\
\text { government support and } \\
\text { market opportunities for } \\
\text { tourist visits } \\
\text { And improving the } \\
\text { quality of facilities in the } \\
\text { region }\end{array}$ & $\begin{array}{l}\text { Develop potential commodity } \\
\text { assets } \\
\text { Areas with potential assets are } \\
\text { supported by adequate facilities } \\
\text { and infrastructures }\end{array}$ & $\begin{array}{l}\text { Increased tourist visits } \\
\text { Increased investment } \\
\text { promotion } \\
\text { Map potential investment areas } \\
\text { Development and } \\
\text { improvement of infrastructure }\end{array}$ & $\begin{array}{l}\text { The existence of } \\
\text { government intervention on } \\
\text { improving the management } \\
\text { of potential assets } \\
\text { Prepare adequate } \\
\text { infrastructure }\end{array}$ \\
\hline
\end{tabular}

